IZA DP No. 6797

Pension Coverage for Parents and Educational Investment in Children: Evidence from Urban China

Ren $\mathrm{Mu}$

Yang Du

August 2012 


\title{
Pension Coverage for Parents and Educational Investment in Children: Evidence from Urban China
}

\author{
Ren Mu \\ Texas A\&M University \\ and IZA \\ Yang Du \\ Chinese Academy of Social Sciences \\ Discussion Paper No. 6797 \\ August 2012 \\ IZA \\ P.O. Box 7240 \\ 53072 Bonn \\ Germany \\ Phone: +49-228-3894-0 \\ Fax: +49-228-3894-180 \\ E-mail: iza@iza.org
}

\begin{abstract}
Any opinions expressed here are those of the author(s) and not those of IZA. Research published in this series may include views on policy, but the institute itself takes no institutional policy positions.

The Institute for the Study of Labor (IZA) in Bonn is a local and virtual international research center and a place of communication between science, politics and business. IZA is an independent nonprofit organization supported by Deutsche Post Foundation. The center is associated with the University of Bonn and offers a stimulating research environment through its international network, workshops and conferences, data service, project support, research visits and doctoral program. IZA engages in (i) original and internationally competitive research in all fields of labor economics, (ii) development of policy concepts, and (iii) dissemination of research results and concepts to the interested public.
\end{abstract}

IZA Discussion Papers often represent preliminary work and are circulated to encourage discussion. Citation of such a paper should account for its provisional character. A revised version may be available directly from the author. 


\section{ABSTRACT \\ Pension Coverage for Parents and Educational Investment in Children: Evidence from Urban China}

When social security is established to provide pensions to parents, their reliance upon children for future financial support decreases; and their need to save for retirement also falls. We use the expansion of pension coverage from the state sector to the non-state sector in urban China as a quasi-experiment to analyze the intergenerational impact of social security on educational investments in children. With a difference-in-differences framework, we find a significant increase in the total education expenditure attributable to pension expansion. The results are unlikely to be driven by trends in medical insurance, wages, bonus income, and housing values. They are robust to the inclusion of a large set of control variables and to different specifications, including one based on the instrumental variable method.

JEL Classification: J26, J24, O15, D13

Keywords: $\quad$ pension, education expenditure, gender difference, urban, China

Corresponding author:

Ren $\mathrm{Mu}$

The Bush School of Government and Public Service

Texas A\&M University

4220 TAMU

College Station, TX 77843

USA

E-mail: rmu@tamu.edu

\footnotetext{
"We have benefited from discussions with Fang Cai, Jin Feng, John Giles, Lisa Kahn, Quan Li, Xiaobo Lu, Albert Park, Lori Taylor and the seminar participants in Beijing University. Feng Huang has provided excellent research assistance.
} 


\section{Introduction}

With declining fertility and increasing life expectancy in many developing countries, governments will soon have to introduce pensions to provide for the needs of a growing elderly population. Pension programs are likely to have profound implications for labor markets, economic growth, and the distribution of risks and income by generation. This paper focuses on the intergenerational effects of a pension program on education in urban China.

The old-age security motive for fertility is well recognized in the developing world. In countries where the capital market is underdeveloped and important social welfare institutions are lacking, individuals without insurance and old-age security have the incentive to invest in the future in the form of children (e.g. Cain, 1983; Nugent, 1987). ${ }^{1}$ As the transfer from children to parents and the survival of parents are both positively correlated with the level of children's education (Cai, et al., 2006; Lei, et al., 2011; Lillard and Willis, 1996; Zimmer et al., 2007;), support in old age may also constitute a motive for providing children with human capital as part of an explicit or implicit intergenerational contract (Pollak, 1988; Raut, 1990) ${ }^{2}$. This old-age security motive for investment in children's education is possibly more credible when the number of children a family can have is limited by strict family planning policies, like those

\footnotetext{
${ }^{1}$ Consequently, the growth in social security and other transfer payments to the elderly is believed to have contributed to the decline in fertility (e.g. Hohm 1975).

${ }^{2}$ Even if parents who leave sizable bequests and do not need support in old age from children can indirectly save for old age by investing in children's education and then reducing bequests when elderly (Becker 1992).
} 
implemented in China. In this case, parents' choice is not on child quantity but on child quality. ${ }^{3}$

When social security is established to provide pensions to parents in old age, their reliance upon children for future financial support decreases. At the same time, their need to save for retirement also falls. The declining role of children in the support of elder parents and the need of parents to save less may simultaneously influence parents' decisions to invest in children's education, but in the opposite direction - the former implies a decline in the investment, but the latter may lead to an increase.

This paper is the first study to assess the intergenerational impact of the expansion of social security on a family's education expenditures on children. For identification purposes, we utilize one pension reform in urban China as a quasi-natural experiment. The reform entails an expansion of pension coverage from employees in the state sector to those in the non-state sector. Employees in the state sector, including government agencies, publicly financed social services (e.g. schools, youth organizations, and health care providers etc.), and state-owned enterprises (SOEs), have long been covered by social security, but no mandate for non-state employers to enroll their employees in the public pension program until 1999 (State Council, 1999; 2000).

In the empirical analysis, we apply a difference-in-differences framework, in which trends in expenditures for the education of children who have a parent employed in the state sector are used to gauge counterfactual trends for what education expenditures

\footnotetext{
${ }^{3}$ As suggested by the influential quantity-quality model in Becker and Lewis (1973), parents may increase child quality when they have fewer children by allocating more resources to each child. This quality gain can happen in the absence of old-age motive.
} 
would have been for children with both parents in the non-state sector. We first demonstrate that other trends, such as those in medical insurance, wages, bonus income, and housing values, are indistinguishable between the two sectors. Moreover, we illustrate that individual determinants of working in the state or non-state sector don't change over time. We then show a statistically significant increase in family education expenditures attributable to the pension reform. The result is robust to the inclusion of a large set of control variables and to different specifications, including one based on the instrumental variable method.

This paper contributes to the knowledge of motivation for parental investment in children. No consensus appears in the economics literature regarding what motivates parents to make transfers to or investments in children. In Becker's classic model (1974), parents are altruistic. ${ }^{4}$ In later models of bequests (Bernheim et al.,1985) and parental investments in children (Raul, 1990), parents are depicted as making strategic decisions based on expected service or transfers from children. Equally mixed is empirical evidence. Some studies support the altruistic motive hypothesis (e.g. McGarry and Schoeni, 1995); some question it or show a mixture of altruistic and exchange motives in parents (e.g. Cox, 1990). This study provides new evidence in this inquiry. If the exchange motive, more specifically the old-age security motive, dominates parental decisions on investing in children's human capital, then with social pensions becoming available to parents, we expect such investment not to increase. An opposite finding indicates that the exchange motive is unlikely to be the driving force in such a decision.

\footnotetext{
${ }^{4}$ Altruistic transfers from parents to children may also be made to offset inequality in children's earnings (Behrman et al., 1982).
} 
This study also relates to the literature on the intergenerational effects of welfare reform on education. Studies of changes in the U.S. national welfare system in the 1990s, aimed at promoting adult employment and reducing long-term dependence on public assistance, have generally yielded positive findings with regard to educational attainment in adolescents (Miller and Zhang, 2011) and young children (Duncan and ChaseLansdale, 2001; Morris et al., 2005, Zaslow et al., 2002). These findings in the US have advanced our understanding of the effects of social programs on education, but an open question remains whether such a finding generalizes to developing countries, where parents' investment in their children's human capital may be motivated by old-age security. This study provides evidence on this issue from a less developed country.

In addition, our study advances the debate and discussion on the impact of pension provisions in developing countries in general and pension reform in China in particular. Several studies have analyzed the gender specific impact of old-age pensions in South Africa, and find that pensions have reduced the labor supply of prime-age individuals; and positively affected the nutritional status of children (Bertrand et al., 2003; Duflo, 2003). In contrast, much of the discussion on China has focused on the limitations of the pension system and ways to improve its efficiencies (e.g. Li, 2011; Salditt et.al., 2007; Zhao and $\mathrm{Xu}, 2004)$, however, evidence of policy impacts is lacking with the exception of a recent study that relates higher household savings to pension reform in state-owned enterprises (Feng et.al., 2011).

Another contribution of this study is that we use total monetary spending on tuitions, school fees, tutors, and extracurricular programs to measure educational investments. Studies of the accumulation of human capital often focus on school 
enrollment or dropout rates. These extensive measures of schooling may miss the quality of educations, a crucial dimension of human capital differentials, especially in settings where little difference exists in age-specific enrollment among children. Intensive measures of education inputs, that is, the actual amount of money spent on education and related activities have more variations that can be explored to detect impact on investment in education.

The remainder of the paper is organized as follows: Section 2 provides a review of cultural and institutional background for elderly support in China. Section 3 presents a simple conceptual framework linking pension coverage for parents and their decisions for investing in their children's education. Section 4 discusses our empirical approach and data. Section 5 reports the results, and Section 6 concludes.

\section{Background: Elderly Support and the Pension System in Urban China}

According to Confucian teaching, filial piety is the root of all virtues. The practice of honoring parents, including providing material means to support them in old age, is therefore inextricably ingrained in the moral fiber of Chinese society. Since 1950, taking care of the elderly has become more than just an informal social norm — it has been formally codified as a legal obligation for children. ${ }^{5}$ Not surprisingly, family was,

\footnotetext{
${ }^{5}$ The Marriage Law of 1950 states that children should support elderly parents, and the Constitution of 1954 emphasizes that children have a duty to support parents (see Fang, Wang, and Song 1992; World Bank 1994). The Marriage Law (2001) further emphasizes this responsibility and endows elderly parents with the right to sue children for support if they fail to provide assistance.
} 
and still is, the primary care provider of the nursing needs and financial support for the elderly. ${ }^{6}$

The traditional role of family in elder care is fraught with new challenges, largely the result of smaller family size and greater labor mobility. The Chinese "one-child" policy, effectively enforced during the past three decades, has reduced family size. Concerns have been raised about the viability of the family support system because the young can now go anywhere for job opportunities. Parents doubt that filial duty will remain a motivational force for their singletons and they also worry about the burden of caring for four elderly parents placed upon young couples (Fong, 2004).

Notwithstanding these concerns and the decline multi-generation co-residence over time, several studies conclude that adult children in China are still responsive to the needs of their parents. Rural children will forgo migration opportunities and stay in their home villages when one or both of their elderly parents are sick (Giles and Mu 2007). Urban children provide more monetary transfers to parents when needed (Cai, Giles, and Meng 2006). More recently, a study based on the new China Health and Retirement Longitudinal Study emphasizes that the living arrangements for the elderly are such that care from a child, either co-resident or in a nearby community, is readily available for more than $70 \%$ of the elderly (Lei et. al., 2011).

Compared to family support, private saving is a secondary option for the provision of elders. This option is likely to be viable only for high-income families,

\footnotetext{
${ }^{6}$ Under the mode of traditional filial piety in China, sons are responsible for care of elder parents. As shown in Ebenstein and Leung (2010), parents without a son are more likely to participate in old-age pension programs in rural areas.
} 
because small savers are predominant among the current elderly. In 1995 the value of financial assets was less than half the annual earnings for $53 \%$ of the urban population aged 55 or older (Jackson and Howe 2004). The percentage of households with wealthto-income ratio of more than two at retirement will remain small in the future (Takayama 2002).

The third source of old-age income is social pension. Since the early 1950s, urban residents who worked in government, government sponsored non-profit institutions, and SOEs have been entitled to social security, including pension coverage. Economic restructuring in SOEs eventually relieved the enterprises from the burden of providing social security for their employees. This change has been made possible by several policy reforms. In 1991, following experiments in a number of provinces and municipalities, the State Council outlined the first major pension reform. ${ }^{7}$ The idea was to promote the integration of pensions for enterprise workers at the provincial level. The social pooling remained a "pay-as-you-go" (PAYG) system, in which mandatory contributions from enterprises and payroll taxes from workers were collected to pay then then current retirees.

With concerns about sustainability of a PAYG system for a rapidly aging population, further reform of the pension system for enterprise workers was initiated in

\footnotetext{
${ }^{7}$ See the 1991 State Council Resolution on the Reform of the Pension System for Enterprise Workers.
} 
the mid-1990s. ${ }^{8}$ As a result, a mandatory system consisting of social pooling and individual accounts was established. The social pooling pillar is based on PAYG, relying on a $20 \%$ payroll tax paid by the enterprises to pay for the current pensions. Individual accounts, purported to be fully funded were financed with contributions of $8 \%$ from enterprises and 3\% from individuals. Voluntary pensions outside the mandatory system, including enterprise annuity plans, individual savings, and other pension plans organized by industries or localities, were also encouraged (Barr and Diamond, 2010).

Although employees of SOEs were covered by the system described above, the coverage for workers outside the state sector was very limited. To facilitate SOE reforms as well as to improve the financial balance of the pension program, the next step in pension reform was to expand the pension pool and encourage contributions from employers and workers in the non-state sector (Zhao and Xu, 2002). In 1999, the State Council called for the acceleration of the inclusion of non-state enterprises workers into the pension pool (State Council 1999). Since then the pension coverage in the non-state enterprise has increased, even though it remains far lower than in the state-sector due to non-compliance (Zhao and $\mathrm{Xu}, 2002)$.

Public employees are covered by a different system, which operates without contributions by workers and with benefits based on a short period of earnings at the end of a career (Barr and Diamond, 2010). Compared to the pension program for enterprises, the system for public employment has undergone little change.

\footnotetext{
${ }^{8}$ The two crucial policy documents were the 1995 State Council Circular on Deepening the Reform of the Old-Age Pension System for Enterprise Employees and the 1997 State Council Document No. 26.
} 
In sum, employees in the state-sector, including SOEs and the public sector, have always been entitled to pension coverage, even though the structure of the pension program for SOE employees has gone through many changes. Only in the early 2000s were workers in non-state sectors brought into the public pension system.

\section{The Link between Pension and Education Expenditure}

Investment in children's human capital is largely made by parents. As pointed out in Becker and Murphy (1988), even altruistic parents have to consider the trade-off between their consumption and the human capital of children because parents must reduce their own consumption (including leisure) to acquire the time and resources they spend on child care and children's education, training, and health. ${ }^{9}$

Consider in a simple version of two-period model, the parents have a timeseparable concave utility function defined over their family consumption in period one $\left(C_{1}\right)$, their own consumption and their child's level of well-being in period two $\left(C_{2}\right.$ and $V)$ :

$$
U_{1}\left(C_{1}\right)+\beta U_{2}\left(C_{2}, \alpha V(e)\right)
$$

where $\beta \in(0,1)$ is the discount factor and $\alpha$ is the weight the parents place on the child's welfare. We assume that the child's level of well-being is a function of his or her education $(e)$.

In period one, the parents use their money income $(y)$ for family consumption, child education and saving $(s)$. In period two, their consumption is determined the saving, transfer from their child $(T)$ and the pension income $(P)$. Assume the return on

\footnotetext{
${ }^{9}$ Only rich parents can avoid this trade-off because they can use bequests to help finance their investments in children (Becker and Murphy, 1988).
} 
saving is $R$, and the transfer is a linear function of the child's education, that is, $T=\gamma e$. Thus, the budget constraints for parents are

$$
C_{1}+e+s=y
$$

and

$$
C_{2}=R s+\gamma e+P
$$

Choosing $C_{1}$ and $e$ to maximize (1) yields the following equation:

$$
\beta U_{2}^{2} \alpha V^{\prime}+\beta \gamma U_{2}^{1}=U_{1}^{\prime}
$$

where the partial derivatives of the utility functions are denoted by superscripts. This intertemporal first-order condition dictates the trade-off between $C_{1}$ and $e$ is such that the utility loss of one unit reduction in $C_{1}$ is equal to the present value of the utility gains from one unit increase in $e$ for time two. The utility gains include the gain from the consumption increase due to more transfer $\left(\beta \gamma U_{2}^{1}\right)$; and the gain due to an increase in the child's welfare $\left(\beta U_{2}^{2} \alpha V^{\prime}\right)$.

With this general framework, we can focus on three cases, each of which uniquely defines parental motives in investing in the education of their child:

Case 1. Parents only have the exchange motive. That is, the child's well-being carries zero weight in their parents' utility function, but the parents rely on the child's transfer for consumption in the later period. This case can be denoted by $\alpha=0$ and $\gamma>$ 0. The first-order condition in Eq. (4) reduces to:

$$
\beta \gamma U_{2}^{1}=U_{1}^{\prime}
$$

To study the effects of changes in pension income $P$ on $e$, we apply the implicit function theorem and obtain the following comparative statics: 


$$
\frac{d e}{d P}=-\frac{\gamma \beta U_{2}^{11}}{\gamma^{2} \beta U_{2}^{11}+U_{1}^{\prime \prime}}
$$

Given the concavity of the utility functions, we know $U_{2}^{11}<0 ; U_{1}^{\prime \prime}<0$ (also $U_{2}^{22}<$ 0 and $\left.V^{\prime \prime}<0\right)$. Therefore, it follows that

$$
\frac{d e}{d P}<0
$$

Case 2. Parents are altruistic. They value their child's well-being, but don't depend on the child's transfer for consumption in period two. That is, $\alpha>0$ and $\gamma=0$. The comparative statics now takes the following form:

$$
\frac{d e}{d P}=-\frac{\beta U_{2}^{21}}{\beta \alpha U_{2}^{22} V^{\prime} V^{\prime}+\beta \alpha U_{2}^{2} V^{\prime \prime}+U_{1}^{\prime \prime}}
$$

It is reasonable to assume that the utility gain that the altruistic parents derive from more consumption is enhanced by improved well-being of their child. In notional term, this can be expressed as $U_{2}^{21}>0$. With this assumption, it follows that

$$
\frac{d e}{d P}>0
$$

Case 3. Parents care about their child's welfare, but they also depend on the child for consumption in period two. Therefore, we have both $\alpha>0$ and $\gamma>0$. The change in $e$ with respect to the change in $P$ is:

$$
\frac{d e}{d P}=-\frac{\beta \alpha U_{2}^{21} V^{\prime}+\gamma \beta U_{2}^{11}}{2 \beta \alpha \gamma U_{2}^{21} V^{\prime}+\beta \alpha^{2} U_{2}^{22} V^{\prime} V^{\prime}+\beta \alpha U_{2}^{2} V^{\prime \prime}+\gamma^{2} \beta U_{2}^{11}+U_{1}^{\prime \prime}}
$$

In this case, the sign of $\frac{d e}{d P}$ is undetermined.

In summary, non-altruistic parents with the exchange motive would decrease the education expenditure for their child in response to new pension availability. In contrast, 
altruistic parents will respond by increasing the education expenditure. Parents who have a mixture of altruistic and exchange motives may either increase or reduce the education expenditure, depending on factors that are traced in this framework.

\section{Empirical Framework}

As outlined above, pension availability may have opposing effects of investments in children's education; therefore, its net effect is inherently an empirical question. In this section we explain the empirical strategies for identification, followed by a discussion of the data.

\subsection{Identification Strategies}

We estimate the net effect of pension expansion on parents' investments in their children's education investments in a difference-in-differences framework:

$$
\begin{gathered}
E_{i c t}=\beta_{1} \text { NonState }_{i c t}+\beta_{2} \text { Year } 2005+\beta_{3} \text { NonState }_{i c t} \times \text { Year } 2005+X_{i c t}^{\prime} \beta_{4} \\
+H_{i c t}^{\prime} \beta_{5}+D_{c \times t}+\varepsilon_{i c t}
\end{gathered}
$$

where $E_{i c t}$ denotes the education investments in child $i$ in city $c$ at time $t$. The variable NonState $_{\text {ict }}$ is a binary variable indexing whether two parents are currently or last employed in the non-state sector. ${ }^{10}$ The post pension reform trend (Year 2005) is estimated using children whose parent(s) is employed in or retired from the state sector.

\footnotetext{
${ }^{10}$ The non-state sector includes collectively owned or controlled enterprises; privately owned or controlled enterprises (with 8 or more employees); foreign-owned or controlled enterprises; privately owned enterprises (with 7 or fewer employees), the self-employed, and other types. The state sector includes government agencies, social service units (e.g., schools, youth organizations, and health care providers, etc.) and state-owned or controlled enterprises.
} 
The treatment effect of pension reform is measured by the coefficient $\left(\beta_{3}\right)$ on the

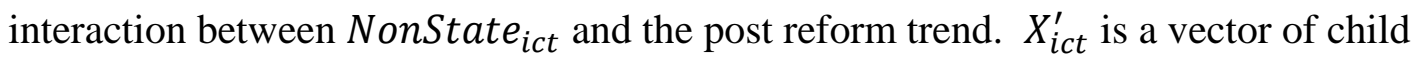
characteristics, including age, gender, and school level. ${ }^{11}$

A vector of parents characteristics is denoted by $H_{i c t}^{\prime}$, in which we control not only for the conventional variables, such as age and years of schooling; but also for parents' family background information, uniquely available in the data. The inclusion of parents' family background as controls is important in mitigating a potential omitted variable bias in the estimation. For example, if the academic ability of a child is positively correlated with the amount of investment made by parents, an upward bias would result if ability is inheritable and high-ability parents are more likely to work for employers who enroll in the public pension program. In addition, parents' time preference can be another omitted variable - myopic parents may choose current consumption over future consumption; and consequently invest less in both children's education and their own retirement. The quality of schooling that parents experienced when they attended school may not only affect the type of employers that they may have later on; but also the way they view the value of education and consequently their decision on their investment in children's. These characteristics are not observed but they are shaped by their family background. Therefore, we include parents' Hukou status

\footnotetext{
${ }^{11}$ There is no need to control for the number of siblings, since vast majority of the children are the only child of their family. In our sample, the average number of siblings a child has is 0.084 .
} 
at the age of $16^{12}$; the number of siblings they have; and their parents' education as additional control variables. In addition, the city-specific year dummies $\left(D_{c \times t}\right)$ are included to control for city-specific policy changes during this period. The idiosyncratic error term is denoted by $\varepsilon_{i c t}$.

The assumption underlying this identification is that the two groups (parent in the state sector and parents in the non-state sector) experience otherwise similar changes in investments in education during the period. Therefore, the observed trend in education expenditure for children among parent in the state sector provides an appropriate counterfactual estimate for what would have happened to children with parents in the non-state sector in the absence of pension reform. Conditional on covariates, we assume that pension coverage is the only systematic factor that has a differential impact on children who have parents in the non-state sector. Although this assumption is not directly testable, we can use the same double-difference framework to examine whether the trends in other social policies and income measures during this period are indeed indistinguishable between the two sectors. The medical reform in 1997 is a major concern because it involves establishing a unified "urban employee basic health insurance scheme" and widening coverage of health insurance for the urban employed (Liu 2002). In addition, we are concerned that wage, bonus, and housing value might reveal different trends in the two sectors. To examine these trends, we estimate the following equation,

\footnotetext{
${ }^{12}$ Hukou status (rural vs. urban) at age of 16 may account for variations in the quality of education the parents had because urban schools are generally better than rural schools (e.g. Paine and Fang, 2007).
} 


$$
\begin{gathered}
Y_{i c t}=\alpha_{1} \text { NonState }_{i c t}+\alpha_{2}{\text { Year2 } 2005+\alpha_{3} \text { NonState }_{i c t}} \times{\text { Year } 2005+Z_{i c t}^{\prime} \alpha_{4}}^{+} D_{c \times t}+\varepsilon_{i c t}
\end{gathered}
$$

where $i$ indexes the working age individual and $Y_{i c t}$ stands for the aforementioned outcomes. $Z_{i c t}^{\prime}$ is a vector of covariates including the individual's age and years of schooling. A small and insignificant estimate of $\alpha_{3}$ supports the view that other trends are not systematically different in state and non-state sectors.

To provide additional robustness checks to the estimation results of Eq. (11), we make use of the 2005 Chinese national intercensal population survey ${ }^{13}$ in addition to CULS; and apply the instrumental variable method to estimate the following equation

$$
E_{i c}=\gamma_{1} \text { Pension }_{i}+X_{i c}^{\prime} \gamma_{2}+H_{i c}^{\prime} \gamma_{3}+D_{c}+\varepsilon_{i c}
$$

in which pension coverage for parent of child $i$, denoted by Pension $i$ is directly included as a covariate. It is a binary variable equal to 1 if at least one parent has enrolled in the pension program; 0 otherwise. We construct two instrumental variables for Pension $_{i}$, and they are the predicted probabilities of enrolling in the public pension program for the mother and the father. The predicted probabilities are the average enrollment rates for each age/education/gender/employer type ${ }^{14} /$ city cell calculated from the 2005 population

${ }^{13}$ We have access to $20 \%$ of the observations in the total sample, and they account for $0.95 \%$ of Chinese population.

${ }^{14}$ There are eight categories for employer types in 2005 population survey: land contractor, government agencies and social service units, state-owned or controlled enterprises, collective enterprises, the self-employed, private enterprises, other enterprises and others. We exclude the land contractor category and combine "other enterprises" and "others" in the calculation. 
survey. This instrument varies by age, education, gender, employer ownership type, and city, and each of these factors is controlled for linearly in Eq. (13). The identification comes only from their interactions, which we assume to be exogenous to parental decisions on investment in education. Others have used the prevailing average as instrument variables in previous studies on health insurance in the US (e.g. Cutler and Gruber, 1996; Gruber and McKnight, 2003). One obvious disadvantage of using this method in our study is that we can use only 2005 data with a much smaller sample; therefore, we only use this approach as a robustness check. We proceed with the doubledifference framework outlined in Eq. (11) to examine potential differential impact on girls vs. boys and children with college educated parent vs. those whose parents are less educated.

\subsection{Data and Summary Statistics}

The data used in this paper are from the China Urban Labor Survey I and II (CULS1 and CULS2), conducted in 2001 and 2005, respectively, by the Institute for Population and Labor Economics at the Chinese Academy of Social Sciences. The survey covers five major cities: Fuzhou, Shanghai, Shenyang, Wuhan, and Xian. The proportional population sampling approach is used for both waves. Within each city, an average of 10 registered urban households in each of 70 and 50 neighborhood clusters (shequ) were surveyed in 2001 and 2005, respectively. ${ }^{15}$ Each household head was asked questions about family members. Family members above age 16 who were no longer in

\footnotetext{
${ }^{15}$ The number of neighborhood clusters drawn is proportional to the size of population of street districts (jiedao). On average three neighborhood clusters are randomly sampled for each street district.
} 
school were interviewed individually. The sample includes 3,499 households from the 2001 survey and 2,505 households from the 2005 survey.

In our final analysis sample, which contains children aged 1-18, we have 988 observations in 2001 and 897 in 2005 . About $63 \%$ of young children aged 1-5 are enrolled in daycares. The school enrollment rate is $98 \%$ for children age $6-15$, and $95 \%$ for the 16-18 group. With such high enrollment rates for school age children, it would be difficult to detect impact on education, if any, based on the extensive measures of school outcomes, such as enrollment rates or dropout rates. With the intensive measures of education input, that is, the actual amount of money spent on education and related activities, more variations can be explored in order to examine the impact on investment in education. For this purpose, an education expenditure module is included in the household survey, where information on tuitions and school fees, as well as expenditures on interest classes and extracurricular activities is collected for each household member who is either in daycare or school.

Yearly education expenditures did not change much between 2001 and 2005, and the average was about 2,600 yuan (Table 1). ${ }^{16}$ Tuition and school fees averaged about 2,110 yuan and accounted for $81 \%$ of the total education expenditure in 2001 ; the amount was 1,927 in 2005 , and its share in the total expenditure dropped to $76 \%$. The decrease in tuition and schools fees is likely to be driven by policy, namely the "one fee system" adopted in fall 2004 by three cities (Shanghai, Wuhan, and Shenyang) and designed to

\footnotetext{
${ }^{16}$ The exchange rate between the yuan and the US dollar is 8.27. The expenditure of 2,600 yuan is equal to 314 US dollars.
} 
curb excessive fee collection made by public schools. ${ }^{17}$ Under this system, public primary schools and junior high schools can charge students one time for two items: school fees and textbooks and notebooks fees. The amount of fees is not set by schools but determined uniformly by the Education Bureau in each province, based on a formula adjusted to school levels.

Even though school fees regulated and set by the government decreased, the amount of money spent on tutors or special interest classes and extracurricular activities increased from 486 yuan to 603 yuan. In addition, proportionally more children had tutors or engaged in extracurriculars in 2001 (41\%) than in 2005 (49\%). In the light of the income increase occurring during this period, ${ }^{18}$ more spending on these education activities outside of schools is not surprising. Besides the income effect, additional spending may also reflect a peer effect in that with only one child, parents "compete" to invest in their children in order to enhance their competitiveness in the labor market and marriage market (Wei and Zhang, 2011). In addition, a belief is embraced at elite urban

${ }^{17}$ This practice is a mandate following a regulation jointly issued by the Ministry of Education, the National Development and Reform Committee, and the Ministry of Finance in March 2004. The regulation document is titled "Opinions Regarding Implementing the "One Fee System" during the Mandatory Schooling Phase Nationally." This document can be accessed through the website of the Ministry of Education at: http://202.205.177.9/edoas/website18/48/info21948.htm.

${ }^{18}$ The average household income is 29,029 yuan (3,510 US dollars) in 2001 and 32,829 yuan (3,970 US dollars) in 2005. 
private schools and more by the public that extracurricular activities can help to foster self-confidence in children and stimulate their interest in learning (Lin 2007)

With regard to pension coverage for parents, the numbers show that $77 \%$ of the children had at least one parent with a pension in 2001, and in 2005 the number increased to $80 \%$.. The share of children with two parents having pensions also went up from $42 \%$ in 2001 to $51 \%$ in 2005. More parents worked in the non-state sector in 2005 than in 2001. About $22 \%$ of the children had two parents in the non-state sector in 2001 , and this number increased to $42 \%$ in 2005.

The samples in these two survey rounds are very similar with respect to child age and gender. They are 12 years old on average and half of them are girls. The parent samples are also comparable over the two years in terms of age and years of schooling. Parents in the 2005 sample appear to be less likely to have had a rural Hukou at age of 16; they also have fewer siblings and slightly better educated parents than the parents in the 2001 sample. But none of the differences in parent characteristics are statistically significant between the two samples.

\section{Results}

Before we present the main estimation results of Eq. (11), we want to indirectly validate the assumption of the difference-in-differences framework; that is, the trends in pension coverage differ between the state and the non-state sector; but other trends are the same. More specifically, we examine medical insurance coverage, measures of income, and assets.

Figure 1 presents the locally weighted regression lines for rates of pension coverage, showing that the coverage rates for the state sector exhibit little systematic 
change from 2001 to 2005 . They average around $80 \%$ with older employees having higher coverage rates. For the non-state sector, the average rates jump from about $40 \%$ in 2001 to a little over $60 \%$ in 2005 . The increase applies to employees in all ages.

As we discussed in Section 4, one confounding policy change could be the implementation of the 1997 health care reform, the goal of which is to increase coverage for the urban employed. Indeed, we see in our sample that the health insurance coverage rates increases from an average of $34 \%$ in 2001 to $41 \%$ in 2005 for the employed in the non-state sector. During the same period, employees in the state sector also experience a similar rise in health insurance coverage (Figure 2) from $77 \%$ to $84 \%$. The same trends in medical insurance validate our identification assumption that policy changes other than pension reform do not affect the two sectors differently.

These visual evidences are further confirmed in the difference-in-differences results reported in Table 2. Estimations for working age women are presented in the top panel, and men in the bottom panel. Both women and men in the non-state sector are more likely to be enrolled in the pension program in 2005 relative to 2001, compared to their counterparts in the state sector. But the trends in medical insurance are indistinguishable between the two sectors. In addition, we also check the monthly wage, yearly bonus income, and the values of their houses. Non-state sector employees have lower values for these outcomes, but they have similar changes over time as the state sector employees, evidenced by the small and insignificant coefficients on all the interaction terms.

These results suggest that the relative "returns" to being employees in the nonstate sector haven't changed in the four years. Not surprisingly, when we run a linear 
probability model on parents' likelihood of working in the non-state sector, we find the individual determinants are the same in 2001 and 2005 (Table 3). Results in Table 3 further confirm that individual selections into the non-state sector can be accounted for in a difference-in-differences framework.

\subsection{Main Results}

We report estimates of the overall effects of pension reform on education expenditure in Table 4. The top panel contains results for the logarithm of the total education expenditure, and the lower panel shows whether or not the child had tutors or participated in extracurricular classes.

The first column of Table 4 shows results from the basic difference-in-differences mode including the full set of city and year fixed effects. Pension reform is associated with a significant increase in education expenditure: Compared to education expenditure for children with one parent in state sector, education expenditure for children with two parents in the non-state sector shows an increase of $19.6 \%$ during this period. In the next column, the estimate is $13 \%$, significant at $1 \%$ level, after additional controls for child age, gender, and school level. We further augment the specification with parents' individual characteristics and their family background as covariates, including parents' age and education (column 3), parents' Hukou status (column 4), parents' number of siblings (column 5) and finally grandparents' education (column 6). With this extensive list of covariates, the impact estimate ranges from $11 \%$ to $12.9 \%$, all significant at the 5\% level.

The results of tutoring and extracurricular classes seem to be sensitive to the inclusion of different controls. Only with the addition of child school level as covariate, 
does the impact estimate become significant. It remains significant at the $10 \%$ level with the full set of controls, showing that relatively children with parent in the non-state sector are $4.8 \%$ more likely to have tutors and attend special interest classes.

In Table 5, we examine the effects on two components of the total education expenditure: tuitions and school fees; and expenditure on tutors and extracurricular classes. The estimations for tuitions and fees are somewhat sensitive to the inclusion of additional variables. With the full set of controls, the impact coefficient is not significantly different from zero. Note that which public schools the K-9 children attend is based mainly on the school district of their residence. With the implementation of the "one fee" system the amount of tuition and school fees is capped in the public schools, thus, it is not surprising that we find no impact on tuition and school fees. The estimated impact on the expenditures on tutors and extracurricular classes is large in magnitude (about $40 \%$ ) and significant at the 5\% with full controls. These results imply that the increase in the total education expenditure occurs primarily because of increased participation in and expenses of educational activities outside regular schools.

We have shown that the trends in health insurance policy, wage, bonus income, and housing values are essentially the same for the state and the non-state sectors. So the observed impact on education expenditure for children whose parents are employed in the non-state sector cannot be driven by any of these factors. With the large set of control variables included in the regressions, we conclude that the effects we find on education investments can be ascribed to the expansion of pension coverage to the non-state sector.

\subsection{Robustness Checks}


In this section, we present two robustness checks of the main results. First, we are concerned that even though the pension coverage rate in the state sector as a whole is not affected by the reform, pension wealth is. In particular, under the new pension system, employees under the state owned enterprises are offered lower replacement rates than in the old system (Salditt et al., 2008; Sin, 2005). The decline in the replacement rate for employees of state- owned enterprises is associated with higher savings (Chamon, et al., 2010; Feng, et al., 2011), which in turn may affect education expenditures. To allow for the potential impact on children with parent in employed in state owned enterprises, we use them as an additional "treatment" group. Children with parents in government agencies and social service units, whose pension benefits are not affected by the reform, are the control group.

The results based on this new specification are presented in Table 6. We present the results with the full set of controls for total education expenditure, tuition and fees, expenditures on tutors and extracurricular classes, and having had tutors or participated in extracurricular classes. The results show that education expenditures on children with parents in the state-owned enterprises are no different for children in the control group, whose parents are employed in government or related organizations. This result implies that the change in pension wealth doesn't seem to affect education expenditures. The impact is the result of the change in pension coverage. Children whose parents are in the non-state sector enjoy more educational input in terms of total education expenditure, expenditures on tutors and extracurricular classes, and greater likelihood of having a tutor or participating in extracurricular classes. These results are quantitatively similar to the ones presented in Tables 4 and 5. 
The second robustness check we perform involves an alternative identification based on the instrumental variable (IV) method as outlined in Eq. (13). In this estimation, we directly control for whether or not at least one parent has enrolled in the public pension program. We then use the predicted enrollment probabilities for mothers and fathers as IVs. The predicted probabilities are the average enrollment rates for each age/education/gender/employer type/city cell calculated from the 2005 population survey. We present the IV results in Table 7, together with the F statistic for excluded instruments and the Hansen $\mathbf{J}$ statistic for the overidentification test.

These first-stage tests are passed easily for all four measures of education investments measures. The IV estimate for expenditures on tutors and extracurricular classes is positive but no longer significant, yet the coefficients on pension are precisely estimated for the total expenditure and the likelihood of having tutors and participating in extracurricular activities. The results show that children whose parent has pension coverage enjoy $24 \%$ more education expenditures and are $38 \%$ more likely to have a tutor or participate in extracurricular activities than the children whose parents are not enrolled in the public pension program. Compared to the results based on the DD framework, these two estimated impacts are larger in magnitude, but they further support our conclusion that parental enrollment in the public pension system is conducive to more investment in children's education.

\subsection{Heterogeneities in the Impacts}

Next we stratify the total sample by children's age, gender and parental education so as to examine the heterogeneities in the impact. We carry out the analysis in the DD 
framework as outlined in Eq. (11). For the sake of brevity, we present only results on the total education expenditures.

The results on impact by age are reported in Table 8. Again we start with a basic specification (column 1) and then add more controls (columns 2-7). The children are grouped into three age categories: pre-school age (1-5 years old); K-9 (6-15 years old); and 16-18 years old. The impact seems to be negatively correlated with children's age. For pre-school children, pension coverage is associated with an increase of $70 \%$ in the total education expenditure. This estimate is statistically significant at the 5\% level. For children aged $6-15$, the point estimates range from $11 \%$ to $18 \%$ and they are all significant at the $1 \%$. The impact estimates are negative for children aged $16-18$, but they are not statistically different from zero in most specifications with more controls.

Note that in the Chinese education system, which public school a child attends at the $\mathrm{K}-9$ level is mostly based on residential location. Merit-based selection starts at the high school level. Which high school a student attends depends largely on his or her performance on a citywide high school entrance exam. But parents can also buy their children enrollment at schools one or two notches higher than their exam scores warrant (Fong 2004). The finding that young children (pre-K and K-9), not high school age children, benefit from parents' pension enrollment indicates that the impact may be limited in scope. It doesn't change which type of high school a child attends, and increases only a young child's extracurricular activities.

Next we investigate whether girls and boys benefit similarly from pension reform, stratifying the total sample by child gender. The results are presented in Table 9 . We have about an equal number of observations in the two samples. Impact is precisely 
estimated for girls in all specifications. The result based on the full set of controls implies that education expenditures increased $21 \%$ for children whose parents are in nonstate sectors in 2005, however, estimates for boys are small in magnitude and turn insignificant when more controls are included in the regressions (columns 3-7).

Finally, we use parent's education as a proxy for family income, and estimate the impact separately for children whose parents do not have a college degree and those who have at least one college-educated parent. The results are reported in Table 10. The point estimates for the year 2005 and non-state sector interaction term decrease in magnitude and become statistically insignificant for children with more educated parents. As we would expect, the pension reform has no effect on families less likely to be budget constrained with regard to education expenditure. The impact estimates remain significant for children whose parents are relatively less educated, and they are substantial in magnitude ( 0.17 with the full set of controls).

These results on the heterogeneities of the impact based on parent education are not surprising. As expected, families with less educated parents face more budget constraints, and their investments in education would be more likely to respond to the income effect of pension reform than families with more educated parents.

\section{Conclusions}

This paper presents the analysis of the impact of an expansion of the public pension program in urban China on children's education expenditures. We collect detailed information on expenditures of tuitions and school fees; as well as tutors and extracurricular classes. We estimate the net effect of the pension expansion in a reduced form difference-in-differences framework, using trends in education expenditures of 
children with parent employed in the state sector to gauge counterfactual trends for what would have happened to those whose parents are employed in the non-state sector absent of the pension expansion. The validity of the method is indirectly supported by the fact that employees in the two sectors experience statistically indistinguishable time trends in medical insurance coverage, wage, bonus income, and housing values. The result is robust to the inclusion of a large set of covariates controlling for parents' family background. In addition, the result is also robust to an alternative identification based on the instrumental variable method.

The results in this study yield three implications. One is that social security reform affects intergenerational transfers in a household. Assessment of the impact of reform would be amiss if it does not include such intergenerational effects. Second, the finding that pension coverage for parents increases family expenditure on children's education suggests that investment in children's human capital seems to be dominated by the altruistic concerns of parents. Third, in the one-child family setting, gender difference still exists with regard to educational investment. This finding suggests that parent preference is likely to be predetermined by culture and norms. 
Figure 1. Pension Coverage by Sectors and Years

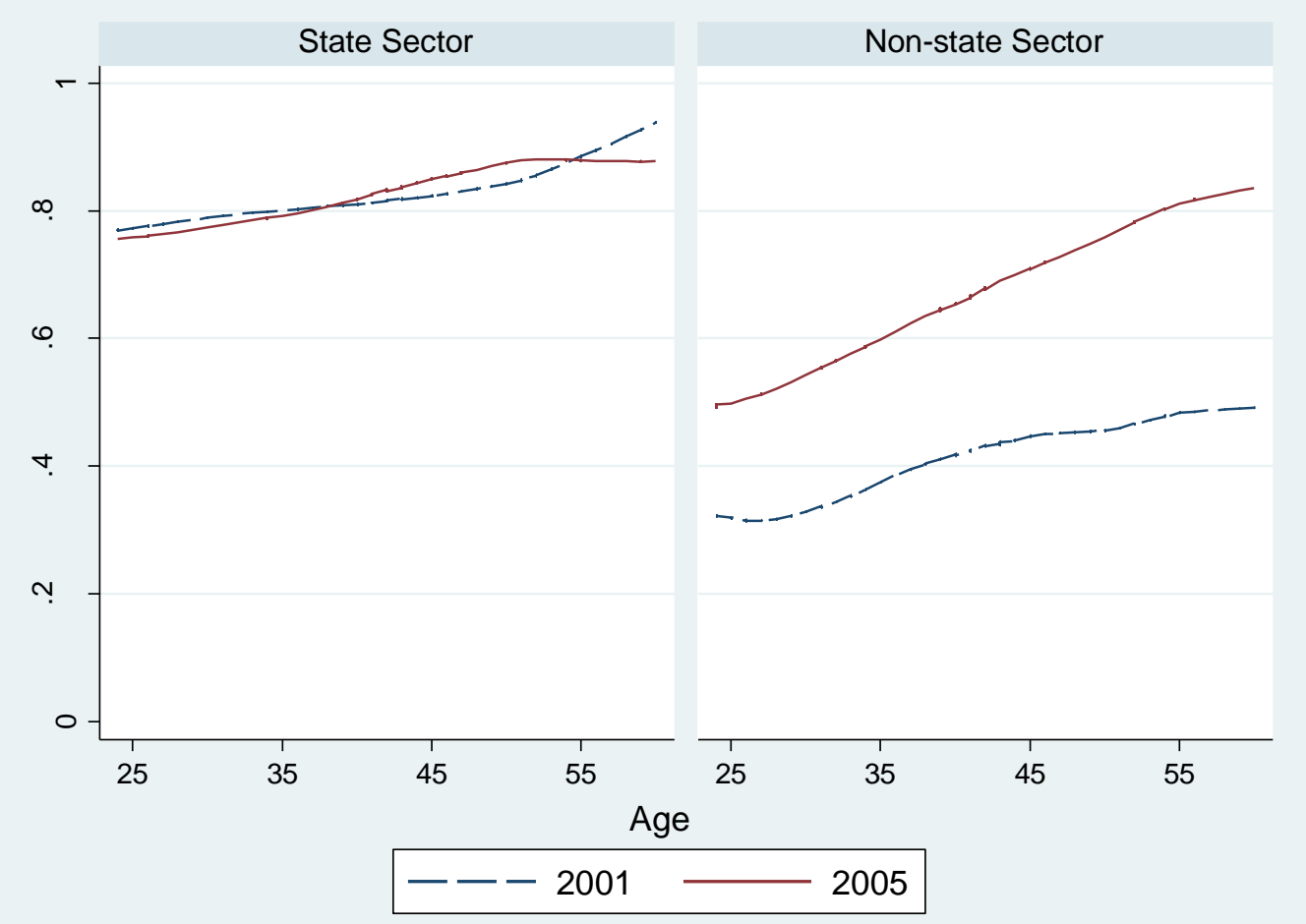

Data source: CULS1 and CULS2 
Figure 2. Medical Insurance Coverage by Sectors and Years

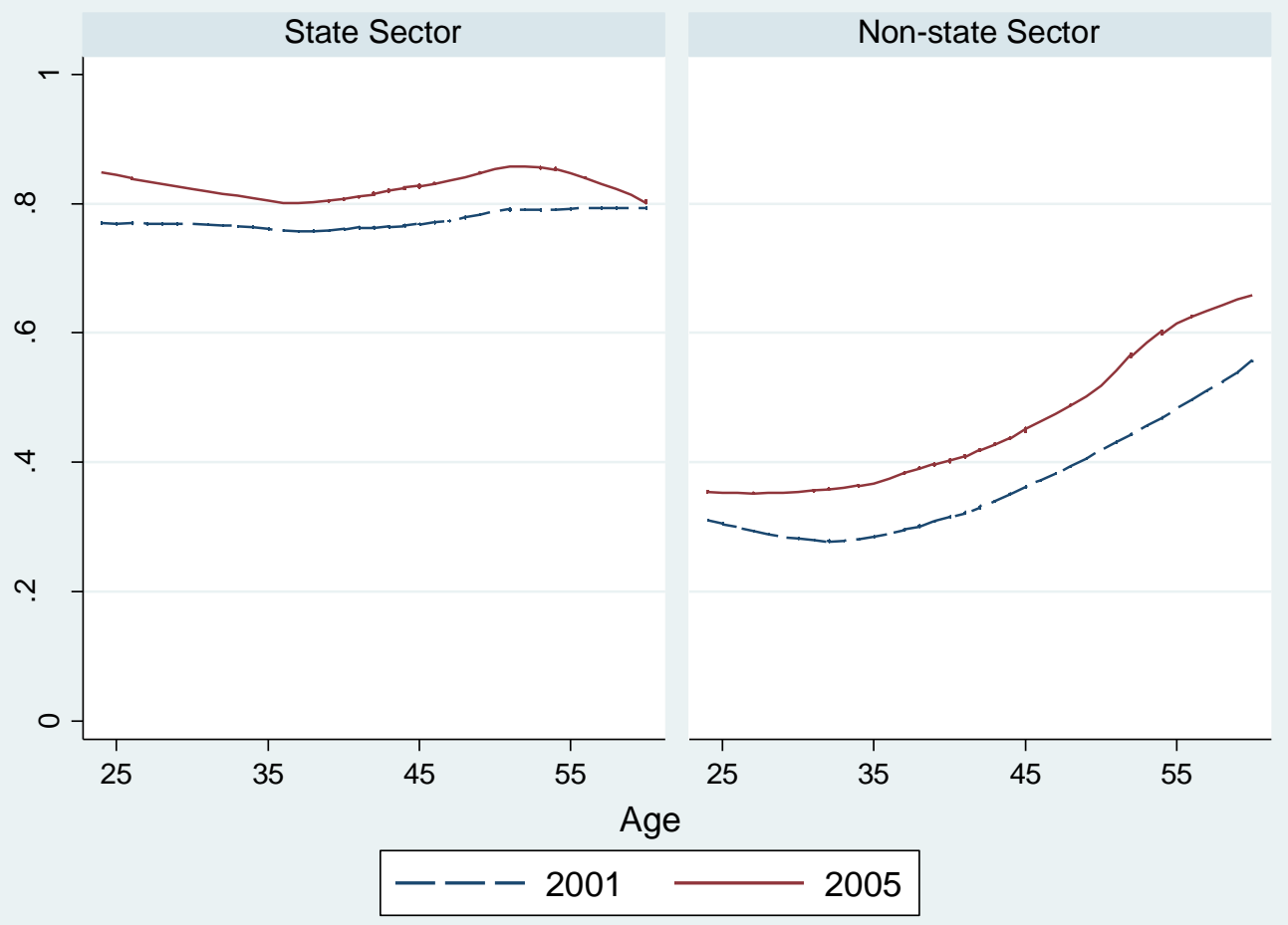

Data source: CULS1 and CULS2 
Table 1 Summary Statistics

\begin{tabular}{|c|c|c|c|c|}
\hline \multirow{2}{*}{ Educational Expenditures } & \multicolumn{2}{|c|}{2001} & \multicolumn{2}{|c|}{2005} \\
\hline & & & & \\
\hline Total Education Expenditure & 2596.21 & $(3364.62)$ & 2535.36 & $(2596.85)$ \\
\hline _. Tuitions and Fees & 2109.75 & $(3041.66)$ & 1926.19 & $(2240.81)$ \\
\hline Tutors and Interest Classes & 486.46 & $(1455.73)$ & 602.73 & $(1161.33)$ \\
\hline Has a Tutor or Enrolled in an Interest Class & 0.41 & $(0.49)$ & 0.49 & $(0.50)$ \\
\hline \multicolumn{5}{|l|}{ Parent Pension Coverage } \\
\hline Mother with Pension Coverage & 0.54 & $(0.50)$ & 0.61 & $(0.49)$ \\
\hline Father with Pensi & 0.65 & $(0.48)$ & 0.70 & $(0.46)$ \\
\hline At Least One Parent with Pension Coverage & 0.77 & $(0.42)$ & 0.80 & $(0.40)$ \\
\hline Both Parents with Pension Coverage & 0.42 & $(0.49)$ & 0.50 & $(0.50)$ \\
\hline \multicolumn{5}{|l|}{ Parent Employment Type } \\
\hline Mother in Non-state Sector & 0.45 & $(0.50)$ & 0.63 & $(0.48)$ \\
\hline Father in Non-state Sector & 0.37 & $(0.48)$ & 0.53 & $(0.50)$ \\
\hline At Least One parent in Non-state Sector & 0.59 & $(0.49)$ & 0.74 & $(0.44)$ \\
\hline Both Parents in Non-state Sector & 0.22 & $(0.42)$ & 0.42 & $(0.49)$ \\
\hline \multicolumn{5}{|l|}{ Child Characteristics } \\
\hline Age & 12.62 & $(4.09)$ & 11.54 & $(5.12)$ \\
\hline Gender & 0.51 & $(0.50)$ & 0.51 & $(0.50)$ \\
\hline \multicolumn{5}{|l|}{ Parent Characteristics } \\
\hline Mother's Age & 39.46 & $(5.31)$ & 39.03 & $(6.20)$ \\
\hline Father's Age & 41.89 & $(5.25)$ & 41.55 & $(6.11)$ \\
\hline Mother's Years of schooling & 11.18 & $(2.70)$ & 11.52 & $(2.49)$ \\
\hline Father's Years of schooling & 11.60 & $(2.97)$ & 11.75 & $(2.57)$ \\
\hline Mother Had a Rural Hukou at Age 16 & 0.19 & $(0.39)$ & 0.15 & $(0.35)$ \\
\hline Father Had a Rural Hukou at Age 16 & 0.15 & $(0.35)$ & 0.11 & $(0.32)$ \\
\hline Mother's Number of Siblings & 2.53 & $(1.45)$ & 3.04 & $(1.51)$ \\
\hline Father's Number of Siblings & 2.58 & $(1.44)$ & 3.06 & $(1.42)$ \\
\hline Maternal Grandmother's Years of Schooling & 4.59 & $(4.44)$ & 5.17 & $(4.01)$ \\
\hline Maternal Grandfather's Years of Schooling & 3.99 & $(4.23)$ & 4.80 & $(4.22)$ \\
\hline Paternal Grandmother's Years of Schooling & 6.79 & $(4.53)$ & 7.21 & $(4.70)$ \\
\hline Paternal Grandfather's Years of Schooling & 6.29 & $(4.61)$ & 6.89 & $(4.60)$ \\
\hline Number of Observations & \multicolumn{2}{|c|}{988} & \multicolumn{2}{|c|}{898} \\
\hline
\end{tabular}

Note: Standard deviations are in the parenthesis. 
Table 2 Double-difference Estimations of Social Security Coverage, Income, and Housing Value

\begin{tabular}{lccccc}
\hline & & Medical & $\begin{array}{c}\text { Monthly } \\
\text { Wage (log) }\end{array}$ & $\begin{array}{c}\text { Yearly } \\
\text { Bonus (log) }\end{array}$ & $\begin{array}{c}\text { Housing } \\
\text { Value }(\log )\end{array}$ \\
\hline Panel A. Women (age 24-55) & & & & & \\
Non-state Sector Y Year 2005 & $0.29 * * *$ & -0.01 & -0.05 & -0.14 & 0.10 \\
& $(0.05)$ & $(0.08)$ & $(0.11)$ & $(0.62)$ & $(0.23)$ \\
Non-state Sector & $-0.44 * * *$ & $-0.35^{* * *}$ & -0.02 & $-1.36^{* * *}$ & $-0.10^{*}$ \\
& $(0.03)$ & $(0.07)$ & $(0.02)$ & $(0.37)$ & $(0.06)$ \\
Year 2005 & -0.02 & $-0.08^{* * *}$ & $0.26 * * *$ & $0.63 * * *$ & $0.39 * * *$ \\
& $(0.02)$ & $(0.02)$ & $(0.04)$ & $(0.19)$ & $(0.06)$ \\
Number of Observations & 5,042 & 5,042 & 4,278 & 4,223 & 5,042 \\
Panel B. Men (age 24-60) & & & & \\
Non-state Sector $\times$ Year 2005 & $0.23 * * *$ & 0.09 & 0.03 & -0.08 & 0.06 \\
& $(0.06)$ & $(0.09)$ & $(0.09)$ & $(0.46)$ & $(0.07)$ \\
Non-state Sector & $-0.34 * * *$ & $-0.40 * * *$ & $-0.13 * * *$ & $-1.03 * * *$ & $-0.14 * * *$ \\
& $(0.03)$ & $(0.08)$ & $(0.04)$ & $(0.24)$ & $(0.04)$ \\
Year 2005 & -0.02 & $-0.09 * * *$ & $0.21 * * *$ & $0.75^{* * *}$ & -0.03 \\
& $(0.02)$ & $(0.03)$ & $(0.04)$ & $(0.19)$ & $(0.02)$ \\
Number of Observations & 4,661 & 4,661 & 3,522 & 3,483 & 4,661 \\
\hline
\end{tabular}

Note: Other variables included but not reported are age, years of schooling, city fixed effects, city-specific time dummies. $* * *$ significant at $1 \%$ level; ** significant at $5 \%$ level; * significant at $10 \%$ level. 
Table 3 Probabilities of Working in the Non-State Sector

\begin{tabular}{|c|c|c|c|c|}
\hline \multirow[b]{2}{*}{ Age } & \multicolumn{2}{|c|}{ Mother } & \multicolumn{2}{|c|}{ Father } \\
\hline & $-0.01 * *$ & $(0.001)$ & -0.00 & $(0.01)$ \\
\hline Years of Schooling & $-0.05 * * *$ & $(0.01)$ & $-0.03 * * *$ & $(0.01)$ \\
\hline Number of Siblings & -0.01 & $(0.01)$ & 0.00 & $(0.01)$ \\
\hline Rural Hukou at Age 16 & 0.05 & $(0.04)$ & $-0.13 * * *$ & $(0.04)$ \\
\hline Father's Years of Schooling & -0.00 & $(0.01)$ & 0.00 & $(0.01)$ \\
\hline Mother's Years of Schooling & $-0.01 * * *$ & $(0.00)$ & $-0.01 * *$ & $(0.00)$ \\
\hline Shanghai & -0.05 & $(0.05)$ & -0.03 & $(0.05)$ \\
\hline Wuhan & 0.01 & $(0.05)$ & 0.02 & $(0.05)$ \\
\hline Shenyang & $0.11 * *$ & $(0.05)$ & 0.07 & $(0.05)$ \\
\hline Fuzhou & 0.04 & $(0.04)$ & 0.04 & $(0.04)$ \\
\hline Year 2005 & $-0.44 * *$ & $(0.22)$ & -0.08 & $(0.22)$ \\
\hline Age $\times$ Year 2005 & 0.01 & $(0.01)$ & -0.00 & $(0.01)$ \\
\hline Years of Schooling $\times$ Year 2005 & -0.00 & $(0.01)$ & -0.01 & $(0.01)$ \\
\hline Number of Siblings $\times$ Year 2005 & 0.02 & $(0.01)$ & 0.01 & $(0.02)$ \\
\hline Rural Hukou at Age $16 \times$ Year 2005 & 0.08 & $(0.06)$ & 0.09 & $(0.06)$ \\
\hline Father's Years of Schooling $\times$ Year 2005 & -0.00 & $(0.01)$ & -0.00 & $(0.01)$ \\
\hline Mother's Years of Schooling $\times$ Year 2005 & 0.01 & $(0.01)$ & 0.00 & $(0.01)$ \\
\hline Shanghai $\times$ Year 2005 & 0.02 & $(0.07)$ & 0.06 & $(0.08)$ \\
\hline Wuhan $\times$ Year 2005 & 0.02 & $(0.06)$ & 0.08 & $(0.07)$ \\
\hline Shenyang $\times$ Year 2005 & $-0.11 *$ & $(0.07)$ & 0.03 & $(0.07)$ \\
\hline Fuzhou $\times$ Year 2005 & -0.18 & $(0.62)$ & 0.01 & $(0.064)$ \\
\hline Constant & $1.53 * * *$ & $(0.17)$ & $0.86^{* * * *}$ & $(0.157)$ \\
\hline Number of Observations & \multicolumn{2}{|c|}{1,886} & \multicolumn{2}{|c|}{1,886} \\
\hline
\end{tabular}

Note: $* * *$ significant at $1 \%$ level; ** significant at $5 \%$ level; $*$ significant at $10 \%$ level.

Standard errors are robust to heteroskedasticity 
Table 4 Double-difference Estimations of Educational Investment for Children Age 1-18

\begin{tabular}{|c|c|c|c|c|c|c|}
\hline & $(1)$ & $(2)$ & $(3)$ & $(4)$ & $(5)$ & $(6)$ \\
\hline \multicolumn{7}{|c|}{ Panel A: Total Education Expenditures (log) } \\
\hline Parents in Non-state Sector $\times$ Year 2005 & $\begin{array}{l}0.196 * \\
(0.111)\end{array}$ & $\begin{array}{c}0.130 * * * \\
(0.044)\end{array}$ & $\begin{array}{c}0.112 * * \\
(0.049)\end{array}$ & $\begin{array}{c}0.113 * * \\
(0.051)\end{array}$ & $\begin{array}{c}0.125 * * \\
(0.053)\end{array}$ & $\begin{array}{c}0.129 * * \\
(0.058)\end{array}$ \\
\hline Parents in Non-state Sector & $\begin{array}{c}-0.328 * * * \\
(0.095)\end{array}$ & $\begin{array}{c}-0.300 * * * \\
(0.036)\end{array}$ & $\begin{array}{c}-0.193 * * * \\
(0.042)\end{array}$ & $\begin{array}{c}-0.182 * * * \\
(0.044)\end{array}$ & $\begin{array}{c}-0.182 * * * \\
(0.044)\end{array}$ & $\begin{array}{c}-0.172 * * * \\
(0.051)\end{array}$ \\
\hline Year 2005 & $\begin{array}{c}0.281 * * * \\
(0.043)\end{array}$ & $\begin{array}{c}0.302 * * * \\
(0.051)\end{array}$ & $\begin{array}{c}0.327 * * * \\
(0.059)\end{array}$ & $\begin{array}{c}0.295 * * * \\
(0.064)\end{array}$ & $\begin{array}{c}0.318 * * * \\
(0.066)\end{array}$ & $\begin{array}{c}0.281 * * * \\
(0.075)\end{array}$ \\
\hline \multicolumn{7}{|c|}{ Panel B: Has Tutors or Enrolled in Interest Classes } \\
\hline Parents in Non-state Sector $\times$ Year 2005 & $\begin{array}{c}0.053 \\
(0.040)\end{array}$ & $\begin{array}{c}0.074 * * \\
(0.035)\end{array}$ & $\begin{array}{l}0.053 * \\
(0.030)\end{array}$ & $\begin{array}{l}0.052 * \\
(0.028)\end{array}$ & $\begin{array}{l}0.050 * \\
(0.029)\end{array}$ & $\begin{array}{l}0.048 * \\
(0.028)\end{array}$ \\
\hline Parents in Non-state Sector & $\begin{array}{c}-0.122 * * * \\
(0.032)\end{array}$ & $\begin{array}{c}-0.134 * * * \\
(0.028)\end{array}$ & $\begin{array}{c}-0.065 * * * \\
(0.018)\end{array}$ & $\begin{array}{c}-0.060 * * * \\
(0.015)\end{array}$ & $\begin{array}{c}-0.060 * * * \\
(0.016)\end{array}$ & $\begin{array}{c}-0.053 * * * \\
(0.015)\end{array}$ \\
\hline Year 2005 & $\begin{array}{c}0.214 * * * \\
(0.031)\end{array}$ & $\begin{array}{c}0.210 * * * \\
(0.034)\end{array}$ & $\begin{array}{c}0.224 * * * \\
(0.041)\end{array}$ & $\begin{array}{c}0.219 * * * \\
(0.042)\end{array}$ & $\begin{array}{c}0.222 * * * \\
(0.042)\end{array}$ & $\begin{array}{c}0.215 * * * \\
(0.041)\end{array}$ \\
\hline City Specific Year Dummies & Yes & Yes & Yes & Yes & Yes & Yes \\
\hline Child Age, Gender and School Level & No & Yes & Yes & Yes & Yes & Yes \\
\hline Age and Education of Parents & No & No & Yes & Yes & Yes & Yes \\
\hline Parents' Hukou Status at Age 16 & No & No & No & Yes & Yes & Yes \\
\hline Parents' Number of Siblings of Parents & No & No & No & No & Yes & Yes \\
\hline Grandparents' Educations & No & No & No & No & No & Yes \\
\hline Number of Observations & 1,886 & 1,886 & 1,886 & 1,886 & 1,886 & 1,886 \\
\hline
\end{tabular}

Note: $* * *$ significant at $1 \%$ level; ** significant at $5 \%$ level; * significant at $10 \%$ level. Standard errors are clustered by

city, year and employers' ownership type. 
Table 5 Double-difference Estimations of Two Types of Education Expenditures for Children Age 1-18

\begin{tabular}{lcccccc}
\hline & $(1)$ & $(2)$ & $(3)$ & $(4)$ & $(5)$ & $(6)$ \\
\hline Panel A: Tuitions and School Fees (log) & & & & & \\
Parents in Non-state Sector $\times$ Year 2005 & $0.171^{* * *}$ & 0.070 & 0.073 & 0.069 & 0.078 & 0.074 \\
& $(0.057)$ & $(0.051)$ & $(0.054)$ & $(0.054)$ & $(0.056)$ & $(0.061)$ \\
Parents in Non-state Sector & $-0.201^{* * *}$ & $-0.159^{* * *}$ & $-0.124^{* *}$ & $-0.116^{* *}$ & $-0.115^{* *}$ & $-0.106^{*}$ \\
& $(0.048)$ & $(0.047)$ & $(0.050)$ & $(0.051)$ & $(0.051)$ & $(0.057)$ \\
& 0.087 & $0.122^{* *}$ & $0.137 * *$ & $0.139^{* *}$ & $0.164^{* * *}$ & $0.147^{* *}$ \\
Year 2005 & $(0.073)$ & $(0.061)$ & $(0.061)$ & $(0.062)$ & $(0.062)$ & $(0.068)$ \\
& & & & \\
Panel B: Expenditures on Tutoring and Interest Classes (log) & & & $0.428^{*}$ & $0.434^{* *}$ \\
Parents in Non-state Sector $\times$ Year 2005 & 0.396 & $0.535^{* *}$ & $0.402^{*}$ & $0.406^{*}$ & $0.219)$ & $(0.215)$ \\
& $(0.266)$ & $(0.241)$ & $(0.212)$ & $(0.213)$ & $(0.219)$ \\
Parents in Non-state Sector & $-0.964^{* * *}$ & $-1.035^{* * *}$ & $-0.495^{* * *}$ & $-0.457^{* * *}$ & $-0.464^{* * *}$ & $-0.423^{* * *}$ \\
& $(0.193)$ & $(0.172)$ & $(0.110)$ & $(0.100)$ & $(0.109)$ & $(0.102)$ \\
Year 2005 & $1.598^{* * *}$ & $1.578^{* * *}$ & $1.688^{* * *}$ & $1.540^{* * *}$ & $1.574^{* * *}$ & $1.478^{* * *}$ \\
& $(0.219)$ & $(0.240)$ & $(0.292)$ & $(0.322)$ & $(0.321)$ & $(0.330)$ \\
\hline City Specific Year Dummies & Yes & Yes & Yes & Yes & Yes & Yes \\
Child Age, Gender and School Level & No & Yes & Yes & Yes & Yes & Yes \\
Age and Education of Parents & No & No & Yes & Yes & Yes & Yes \\
Parents' Hukou Status at Age 16 & No & No & No & Yes & Yes & Yes \\
Parents' Number of Siblings of Parents & No & No & No & No & Yes & Yes \\
Grandparents' Educations & No & No & No & No & No & Yes \\
\hline Number of Observations & 1,886 & 1,886 & 1,886 & 1,886 & 1,886 & 1,886 \\
\hline
\end{tabular}

Note: $* * *$ significant at $1 \%$ level; $* *$ significant at $5 \%$ level; * significant at $10 \%$ level. Standard errors are clustered by

city, year and employers' ownership type. 
Table 6 Robustness Check: Double-Difference Estimations with Parents in State-owned Enterprises as a Control Group

\begin{tabular}{|c|c|c|c|c|}
\hline & $\begin{array}{c}\text { Total } \\
\text { Education } \\
\text { Expenditure } \\
(\log )\end{array}$ & $\begin{array}{c}\text { Tuitions } \\
\text { and School } \\
\text { Fees (log) }\end{array}$ & $\begin{array}{c}\text { Expenditures } \\
\text { on Tutoring } \\
\text { and Interest } \\
\text { Classes }(\log )\end{array}$ & $\begin{array}{c}\text { Has Tutors } \\
\text { or Enrolled } \\
\text { in Interest } \\
\text { Classes }\end{array}$ \\
\hline Parents in Non-state Sector $\times$ Year 2005 & $\begin{array}{c}0.105^{* *} \\
(0.043)\end{array}$ & $\begin{array}{c}0.063 \\
(0.062)\end{array}$ & $\begin{array}{l}0.346^{*} \\
(0.204)\end{array}$ & $\begin{array}{l}0.050 * \\
(0.029)\end{array}$ \\
\hline Parents in Non-state Sector & $\begin{array}{c}-0.309 * * * \\
(0.035)\end{array}$ & $\begin{array}{c}-0.124 * * \\
(0.055)\end{array}$ & $\begin{array}{c}-0.389 * * * \\
(0.113)\end{array}$ & $\begin{array}{c}-0.047 * * * \\
(0.018)\end{array}$ \\
\hline Parent in State-owned Enterprises $\times$ Year 2005 & $\begin{array}{l}-0.150 \\
(0.113)\end{array}$ & $\begin{array}{l}-0.063 \\
(0.101)\end{array}$ & $\begin{array}{c}0.053 \\
(0.347)\end{array}$ & $\begin{array}{c}0.015 \\
(0.050)\end{array}$ \\
\hline Parent in State-owned or State-controlled Enterprises & $\begin{array}{l}-0.041 \\
(0.031)\end{array}$ & $\begin{array}{l}-0.089 \\
(0.063)\end{array}$ & $\begin{array}{c}0.208 \\
(0.231)\end{array}$ & $\begin{array}{c}0.028 \\
(0.038)\end{array}$ \\
\hline Year 2005 & $\begin{array}{c}0.336 * * * \\
(0.053)\end{array}$ & $\begin{array}{l}0.143^{*} \\
(0.084)\end{array}$ & $\begin{array}{c}1.615^{* * *} * \\
(0.279)\end{array}$ & $\begin{array}{c}0.214 * * * \\
(0.041)\end{array}$ \\
\hline City Specific Year Dummies & Yes & Yes & Yes & Yes \\
\hline Child Age, Gender and School Level & Yes & Yes & Yes & Yes \\
\hline Age and Education of Parents & Yes & Yes & Yes & Yes \\
\hline Parents' Hukou Status at Age 16 & Yes & Yes & Yes & Yes \\
\hline Parents' Number of Siblings of Parents & Yes & Yes & Yes & Yes \\
\hline Grandparents' Educations & Yes & Yes & Yes & Yes \\
\hline Number of Observations & 1,885 & 1,885 & 1,885 & 1,885 \\
\hline
\end{tabular}

Note: *** significant at $1 \%$ level; ** significant at $5 \%$ level; * significant at $10 \%$ level. Standard errors are clustered by

city, year and employers' ownership type. 
Table 7 Robustness Check: Instrumental Variable Estimations based on the 2005 CULS and the 2005 Mini Census

\begin{tabular}{|c|c|c|c|c|}
\hline & $\begin{array}{c}\text { Total } \\
\text { Education } \\
\text { Expenditure } \\
\text { (log) }\end{array}$ & $\begin{array}{c}\text { Tuitions and } \\
\text { School Fees } \\
(\log )\end{array}$ & $\begin{array}{l}\text { Expenditures } \\
\text { on Tutoring } \\
\text { and Interest } \\
\text { Classes (log) }\end{array}$ & $\begin{array}{c}\text { Has Tutors or } \\
\text { Enrolled in } \\
\text { Interest } \\
\text { Classes }\end{array}$ \\
\hline Parent(s) Have Pension Coverage & $\begin{array}{c}0.242 * * \\
(0.110)\end{array}$ & $\begin{array}{c}0.089 \\
(0.279)\end{array}$ & $\begin{array}{c}0.190 \\
(0.365)\end{array}$ & $\begin{array}{c}0.378 * * \\
(0.172)\end{array}$ \\
\hline F-test on Excluded Instruments & 22.91 & 21.94 & 20.43 & 22.91 \\
\hline Overidentification: Hansen J statistic & 2.050 & 0.283 & 0.131 & 1.690 \\
\hline Chi-sq p-val & 0.1522 & 0.594 & 0.718 & 0.194 \\
\hline City Fixed Effects & Yes & Yes & Yes & Yes \\
\hline Child Age, Gender and School Level & Yes & Yes & Yes & Yes \\
\hline Age and Education of Parents & Yes & Yes & Yes & Yes \\
\hline Parents' Hukou Status at Age 16 & Yes & Yes & Yes & Yes \\
\hline Grandparents’ Educations & Yes & Yes & Yes & Yes \\
\hline Number of Observations & 898 & 898 & 898 & 898 \\
\hline
\end{tabular}

Note: $* * *$ significant at $1 \%$ level; $* *$ significant at $5 \%$ level; * significant at $10 \%$ level. Standard errors are robust to

heteroskedasticity. The pension variable measures whether or not at least one parent is covered by a public pension program; it is instrumented by two variables: mother's probability of enrolling in public pension program and father's enrollment probability. The probabilities are predicted from a sample consisting of $20 \%$ of the observations of the 2005 Chinese national intercensal population survey, based on the city of residence, age, education level, and employer's ownership type. 
Table 8 Heterogeneities of the Impacts on the Total Education Expenditures by Child Age

\begin{tabular}{|c|c|c|c|c|c|c|}
\hline & $(1)$ & $(2)$ & $(3)$ & $(4)$ & $(5)$ & $(6)$ \\
\hline \multicolumn{7}{|l|}{ Panel A: age 1-5 } \\
\hline Parents in Non-state Sector $\times$ Year 2005 & $\begin{array}{c}0.799 * * \\
(0.320)\end{array}$ & $\begin{array}{l}0.618^{*} \\
(0.317)\end{array}$ & $\begin{array}{c}0.662 * * \\
(0.297)\end{array}$ & $\begin{array}{l}0.596^{*} \\
(0.305)\end{array}$ & $\begin{array}{l}0.647 * \\
(0.338)\end{array}$ & $\begin{array}{c}0.707 * * \\
(0.303)\end{array}$ \\
\hline Number of Observations & 141 & 141 & 141 & 141 & 141 & 141 \\
\hline \multicolumn{7}{|l|}{ Panel B: age 6-15 } \\
\hline Parents in Non-state Sector $\times$ Year 2005 & $\begin{array}{c}0.181 \text { *** } \\
(0.051)\end{array}$ & $\begin{array}{c}0.141 * * * \\
(0.041)\end{array}$ & $\begin{array}{c}0.115^{* * * *} \\
(0.042)\end{array}$ & $\begin{array}{c}0.113 * * * \\
(0.043)\end{array}$ & $\begin{array}{c}0.127 * * * \\
(0.044)\end{array}$ & $\begin{array}{c}0.134 * * * \\
(0.048)\end{array}$ \\
\hline Number of Observations & 1,360 & 1,360 & 1,360 & 1,360 & 1,360 & 1,360 \\
\hline \multicolumn{7}{|l|}{ Panel C: age 16-19 } \\
\hline Parents in Non-state Sector $\times$ Year 2005 & $\begin{array}{c}-0.124 * \\
(0.072)\end{array}$ & $\begin{array}{c}-0.103 \\
(0.087)\end{array}$ & $\begin{array}{l}-0.092 \\
(0.088)\end{array}$ & $\begin{array}{l}-0.090 \\
(0.113)\end{array}$ & $\begin{array}{l}-0.118 \\
(0.122)\end{array}$ & $\begin{array}{l}-0.147 \\
(0.153)\end{array}$ \\
\hline Number of Observations & 208 & 208 & 208 & 208 & 208 & 208 \\
\hline Year Dummy for 2005 & Yes & Yes & Yes & Yes & Yes & Yes \\
\hline Parents in Non-state Sector & Yes & Yes & Yes & Yes & Yes & Yes \\
\hline City Specific Year Dummies & Yes & Yes & Yes & Yes & Yes & Yes \\
\hline Child Age, Gender and School Level & No & Yes & Yes & Yes & Yes & Yes \\
\hline Age and Education of Parents & No & No & Yes & Yes & Yes & Yes \\
\hline Parents' Hukou Status at Age 16 & No & No & No & Yes & Yes & Yes \\
\hline Parents' Number of Siblings of Parents & No & No & No & No & Yes & Yes \\
\hline Grandparents' Educations & No & No & No & No & No & Yes \\
\hline
\end{tabular}

Note: $* * *$ significant at $1 \%$ level; ** significant at $5 \%$ level; * significant at $10 \%$ level. Standard errors are

clustered by city, year and employers' ownership type. 
Table 9 Heterogeneities of the Impacts on the Total Education Expenditures by Child Gender

\begin{tabular}{lcccccc}
\hline & $(1)$ & $(2)$ & $(3)$ & $(4)$ & $(5)$ & $(6)$ \\
\hline Panel A: Girls & & & & & & \\
Parents in Non-state Sector $\times$ Year 2005 & $0.227 * * *$ & $0.175^{* * *}$ & $0.164^{* * *}$ & $0.155^{* * *}$ & $0.171^{* * *}$ & $0.205^{* * *}$ \\
& $(0.059)$ & $(0.059)$ & $(0.061)$ & $(0.059)$ & $(0.060)$ & $(0.064)$ \\
Number of Observations & 929 & 929 & 929 & 929 & 929 & 929 \\
Panel B: Boys & & & & & \\
Parents in Non-state Sector $\times$ Year 2005 & $0.182^{*}$ & 0.081 & 0.058 & 0.058 & 0.079 & 0.076 \\
& $(0.096)$ & $(0.081)$ & $(0.095)$ & $(0.097)$ & $(0.103)$ & $(0.108)$ \\
Number of Observations & 957 & 957 & 957 & 957 & 957 & 957 \\
\hline Year Dummy for 2005 & Yes & Yes & Yes & Yes & Yes & Yes \\
Parents in Non-state Sector & Yes & Yes & Yes & Yes & Yes & Yes \\
City Specific Year Dummies & Yes & Yes & Yes & Yes & Yes & Yes \\
Child Age, Gender and School Level & No & Yes & Yes & Yes & Yes & Yes \\
Age and Education of Parents & No & No & Yes & Yes & Yes & Yes \\
Parents' Hukou Status at Age 16 & No & No & No & Yes & Yes & Yes \\
Parents' Number of Siblings of Parents & No & No & No & No & Yes & Yes \\
Grandparents' Educations & No & No & No & No & No & Yes \\
\hline
\end{tabular}

Note: *** significant at $1 \%$ level; ** significant at $5 \%$ level; * significant at $10 \%$ level. Standard errors are

clustered by city, year and employers' ownership type. 
Table 10 Heterogeneities of the Impacts on the Total Education Expenditures by Parent Education

\begin{tabular}{lcccccc}
\hline & $(1)$ & $(2)$ & $(3)$ & $(4)$ & $(5)$ & $(6)$ \\
\hline Panel A: At Least One Parent Has a College Degree & & & & & \\
Parents in Non-state Sector $\times$ Year 2005 & 0.110 & 0.082 & 0.076 & 0.051 & 0.061 & -0.021 \\
& $(0.123)$ & $(0.126)$ & $(0.124)$ & $(0.141)$ & $(0.160)$ & $(0.159)$ \\
& 522 & 522 & 522 & 522 & 522 & 522 \\
Number of Observations & & & & & & \\
Panel B: No Parent Has a College Degree & & & & & & \\
Parents in Non-state Sector $\times$ Year 2005 & $0.201 * * *$ & $0.128^{*}$ & $0.134 *$ & $0.140 *$ & $0.154^{*}$ & $0.166^{*}$ \\
& $(0.070)$ & $(0.066)$ & $(0.076)$ & $(0.077)$ & $(0.080)$ & $(0.086)$ \\
Number of Observations & 1,364 & 1,364 & 1,364 & 1,364 & 1,364 & 1,364 \\
\hline Year Dummy for 2005 & Yes & Yes & Yes & Yes & Yes & Yes \\
Parents in Non-state Sector & Yes & Yes & Yes & Yes & Yes & Yes \\
City Specific Year Dummies & Yes & Yes & Yes & Yes & Yes & Yes \\
Child Age, Gender and School Level & No & Yes & Yes & Yes & Yes & Yes \\
Age and Education of Parents & No & No & Yes & Yes & Yes & Yes \\
Parents' Hukou Status at Age 16 & No & No & No & Yes & Yes & Yes \\
Parents' Number of Siblings of Parents & No & No & No & No & Yes & Yes \\
Grandparents' Educations & No & No & No & No & No & Yes \\
\hline
\end{tabular}

Note: *** significant at $1 \%$ level; ** significant at $5 \%$ level; * significant at $10 \%$ level. Standard errors are

clustered by city, year and employers' ownership type. 


\section{References:}

Barr, N., and Diamond, P., 2010. Pension reform in China: issues, options and recommendations. Working Paper, the Department of Economics, MIT.

Becker, G., 1974. A theory of social interactions. Journal of Political Economy 82(6): 1063-1093.

Becker, G., 1992. The Economic Way of Looking at Life. Nobel Lecture in Economics, December.

Becker, G., and Lewis, H., 1973. On the interaction between the quantity and quality of children. Journal of Political Economy 81 (2): S279-S288.

Becker, G., and Murphy, K., 1988. The Family and the state. Journal of Law and Economics, Vol. 31, No. 1: 1-18

Behrman, J.R., Pollack, R.A., Taubman, P., 1982. Parental preferences and provision for progeny. Journal of Political Economy 90(1), 52-73.

Bernheim, B.D., Shleifer, A., Summers, L.H., 1985. The strategic bequest motive. Journal of political Economy 93(6): 1045-1076.

Bertrand, M., Mullainathan, S., and Miller, D., 2003. Public policy and extended families: evidence from pensions in South Africa. The World Bank Economic Review, 17(1): 27-50.

Cai, F., Giles, J., and Meng, X., 2006. How well do children insure parents against low retirement income? An analysis using survey data from urban China. Journal of Public Economics 90(12): 2229-2255.

Cain, M. T., 1983. Fertility as an adjustment to risk. Population and Development Review 9:688-702. 
Chamon, M., Liu, K., and Prasad, E., 2010. Income uncertainty and household savings in China. NBER Working Paper 16565.

Cox, D., 1990. Intergenerational transfers and liquidity constraints. Quarterly Journal of Economics 105(1): 187-217.

Cutler, D., Gruber, J., 1996. Does public insurance crowd out private insurance? Quarterly Journal of Economics 111, 391-430.

Duflo, E., 2003. Grandmothers and granddaughters: old-age pensions and intrahousehold allocation in South Africa. The World Bank Economic Review, 17(1): 1-25.

Duncan, G.J. and Chase-Lansdale, P.L., 2001. Welfare reform and children's well-being, In The New World of Welfare. Blank, R.M. and Haskins, R. Eds. Brookings Institution Press: Washington, D.C.: 391-412.

Ebenstein, A. and Leung, S., 2010 Son preference and access to social insurance: evidence from China's rural pension program. Population and Development Review, 36(1): 47-70.

Fang, Y., Wang, C., and Song, Y. 1992. Support for the elderly in China. in Family support for the elderly: the international experience, Kendig, K., Hashimoto, A., and Copport, L. (eds.). New York: Oxford University Press.

Feng , J., He, L., and Sato, H., 2011. Public pension and household saving: evidence from urban China. Journal of Comparative Economics 30: 470-485.

Fong, V., 2004. Only Hope. Stanford University Press, Stanford, California.

Giles, J., and Mu, R., 2007. Elder parent health and the migration decision of adult children: evidence from rural China. Demography 265-288. 
Gruber, J., and McKnight, R., 2003. Why did employee health insurance contributions rise? Journal of Health Economics 22: 1085-1104.

Hohm, C. F., 1975. Social security and fertility: an international perspective. Demography 12(4): 629-644.

Jackson, R., and Howe, N., 2004. The Graying of the Middle Kingdom: The Demographics and Economics of Retirement Policy in China. Washington, D.C: The Center for Strategic and International Studies.

Lei, X., Strauss, J., Tian, M., and Zhao, Y., 2011. Living arrangements of the elderly in China: evidence from CHARLS. IZA Discussion Paper No. 6249

Lin, J. 2007. Emergence of private schools in China: context, characteristics, and implications. In Hannum, E., Park, A. (Eds.), Education and Reform in China, Routledge, New York.

Liu, Y., 2002. Reforming China's urban health insurance system. Health Policy 60: 133150.

McGarry, K., and Schoeni, R.F., 1995. Transfer behavior in the health and retirement study: measurement and the redistribution of resources within the family. Journal of Human Resources 30(0), S184-S226.

Miller, A.R., and Zhang, L. 2011. Intergenerational effects of welfare reform on educational attainment. Journal of Law and Economics, forthcoming.

Morris, P., Duncan, G., and Clark-Kauffman, E., 2005. Child well-being in an era of welfare reform: the sensitivity of transition in development to policy change, Developmental Psychology, 41(6): 919-932.

Nugent, J. B. 1987. The old-age security motive for fertility. Population and Development Review 11:75-97. 
Paine, L., and Fang, Y., 2007. Supporting China's teachers: challenges in reforming professional development. In Hannum, E., Park, A. (Eds.), Education and Reform in China, Routledge, New York.

Pollak, R.A., 1988. Tied transfers and paternalistic preferences. American Economic Review 78(2): 240-244.

Raut, L.K., 1990. Capital accumulation, income distribution and endogenous fertility in an overlapping generations general equilibrium model. Journal of Development Economics 34 (1/2), 123-150.

Salditt, F., Whiteford, P., and Adema, W., 2008. Pension Reform in China. International Social Security Review 63: 47-71.

Sin, Y., 2005. Pension liabilities and reform options for old age insurance. World Bank Working Paper No. 2005-1.

State Council, 1991. Resolution on the Reform of the Pension System for Enterprise Workers

State Council, 1997. A Decision on Establishing a Unified Basic Pension System for Enterprise Workers

State Council, 1999. Tentative Rules on the Payment of Social Security Dues

State Council, 2000. An Experiment to Perfect Urban Social Security System

Takayama, N. 2002. Pension reform of PRC: Incentives, governance and policy options. Paper presented at the ADB Institute Fifth Anniversary Conference on the Challenges and New Agenda for PRC, Tokyo, Japan.

Wei, S., and Zhang, X., 2011. The competitive saving motive: evidence from rising sex ratios and savings in China. Journal of Political Economy, 119 (3): 511-564.

World Bank. 1994. Averting the Old Age Crisis. New York: Oxford University Press for 
the World Bank.

Zaslow, M.J., Moore, K.A., Brooks, J.L., Morris, P.A., Tout, K., Redd, Z.A. and Emig, C.A.,2002. Experimental studies of welfare reform and children. The Future of Children, 12(1): 78-95.

Zhao, Y., and Xu, J., 2002. China's urban pension system: reforms and problems. Cato Journal, Vol. 21, No. 3: 395-414.

Zimmer, Z., Martin, L.G., Ofstedal, M., and Chuang, Y., 2007. Education of adult children and mortality of their elderly parents in Taiwan. Demography, 44(2): 289-305. 